\title{
INEQUALITIES OF THE DUNKL-WILLIAMS TYPE FOR ABSOLUTE VALUE OPERATORS
}

\author{
JOSIP PEČARIĆ AND RAJNA RAJIĆ
}

Abstract. In this paper we give operator-valued versions of some Dunkl-Williams related inequalities for Hilbert space operators. The case of equality is also studied.

Mathematics subject classification (2010): 26D15, 47A63.

Keywords and phrases: Dunkl-Williams inequality, Bohr inequality, triangle inequality, operator inequality.

\section{REFERENCES}

[1] C.A. Akemann, J. Anderson And G.K. Pedersen, Triangle inequalities in operator algebras, Linear Multilinear Algebra, 11, 2 (1982), 167-178.

[2] T. ANDO AND T. HAYASHI, A characterization of the operator-valued triangle equality, J. Operator Theory, 58, 2 (2007), 463-468.

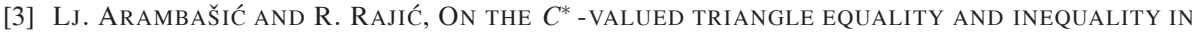
HilberT $C^{*}$-MODUles, Acta Math. Hungar., 119, 4 (2008), 373-380.

[4] J.A. Clarkson, Uniformly convex spaces, Trans. Amer. Math. Soc., 40 (1936), 396-414.

[5] W.S. Cheung AND J. PEČARIĆ, Bohr's inequalities for Hilbert space operators, J. Math. Anal. Appl., 323 (2006), 403-412.

[6] D.G. DeFigueiredo And L.A. Karlovitz, On the radial projection in normed spaces, Bull. Amer. Math. Soc., 73 (1967), 364-368.

[7] C.F. DunKL AND K.S. Williams, A simple norm inequality, Amer. Math. Monthly, 71 (1964), 53-54.

[8] R. HARTE, The triangle inequality in $C^{*}$-algebras, Filomat no. 20, part 2 (2006), 51-53.

[9] O. Hirzallah, Non-commutative operator Bohr inequality, J. Math. Anal. Appl., 282 (2003), 578 583.

[10] M. KATO, K.S. SAITO AND T. TAMURA, Sharp triangle inequality and its reverse in Banach spaces, Math. Inequal. Appl., 10, 2 (2007), 451-460.

[11] E.C. LANCE, Hilbert $C^{*}$-modules, LMS Lecture Note Series, vol. 210, Cambridge University Press, Cambridge, 1995.

[12] L. Maligranda, Simple norm inequalities, Amer. Math. Monthly, 113 (2006), 256-260.

[13] J.L. MASSERA AND J.J. SCHÄFFER, Linear differential equations and functional analysis I, Ann. of Math., 67 (1958), 517-573.

[14] P.R. Mercer, The Dunkl-Williams inequality in an inner-product space, Math. Inequal. Appl., 10, 2 (2007), 447-450.

[15] D.S. Mitrinović, Analytic Inequalities, Springer-Verlag, New York, 1970.

[16] J. PEČARIĆ AND R. RAJIĆ, The Dunkl-Williams equality in pre-Hilbert $C^{*}$-modules, Linear Algebra Appl., 425 (2007), 16-25.

[17] J. PEČARIĆ AND R. RAJIĆ, The Dunkl-Williams inequality with $n$ elements in normed linear spaces, Math. Inequal. Appl., 10, 2 (2007), 461-470.

[18] R.L. TheLE, Some results on the radial projection in Banach spaces, Proc. Amer. Math. Soc., 42, 2 (1974), 483-486.

[19] R.C. Thompson, Convex and concave functions of singular values of matrix sums, Pacific J. Math., 66, 1 (1976), 285-290. 
[20] R.C. Thompson, The case of equality in the matrix-valued triangle inequality, Pacific J. Math., 82, 1 (1979), 279-280.

[21] F. ZHAng, On the Bohr inequality of operators, J. Math. Anal. Appl., 333 (2007), 1264-1271. 